\title{
A CASES OF PULMONARY MYCOSIS COMPLICATING LEPROSY
}

\author{
Kimishige SATO \\ (Dept. of Pathology, Kumamoto University Medical School)
}

Toshiaki KASUGA and Tadae ITO

(National Leprosarium Kikuchi Keihu-en)

A case of leprosy in which pulmonary mycosis occurred was experienced. The patient was a 45 year old male with a history of leprosy of 20 years duration. He had received a total of 87 injections of Promin ( $13.05 \mathrm{~g}$ ) and the manifestations had become stabilized in the early part of 1956 . In Sept. of the same year however, he had become afflicted with pleurisy of the right side. Streptomycin treatment was instituted after one month as there was a slight worsening in the symptoms whereupon he took a sudden turn for the worse with high fever and pain of the throat. The sputum was tuberculosis bacilli negative but a large number of mycotic spores and fibers were found. The general condition rapidly deteriorated and the patient died on November 9, 1956.

Autopsy findings verified the clinical diagnosis and changes due both to leprosy and mycosis were found.

\section{癩に見られた肺真菌症の一剖検例}

\begin{tabular}{|c|c|c|c|c|c|}
\hline 助 & 手 & 佐 & 藤 & 公 & 繁 \\
\hline \multicolumn{6}{|c|}{ 国立瀨療養所菊池患煈園（園長＼cjkstart宮崎松記博士） } \\
\hline 技 & 官 & 春 & 日 & 俊 & 章 \\
\hline 技 & 官 & 伊 & 藤 & 忠 & \\
\hline
\end{tabular}

（昭和 32 年 9 月 18 日受稿）

緒言

真菌症は皮展科及び耳鼻咽喉科領域では相当みられる ものであり, 内科領域においても全身的重篤疾患, 栄養 不良等に続発するものとして知られていた。近来抗生物 質が広く使用される様になり，その直接的な菌の発育促 進作用, 細菌叢の変化による $\mathrm{P} \mathrm{H}$ の変化, 菌交代現象或
は組織抵抗性の減弱等のために, 真菌感染症が増加して きた1)-6)。真菌应はその多くが自家感染であるため，診 断の第一義的な根拠は菌検索であることは勿論であるが この場合反復恒常的に多数の菌を証明し, その固定と, 組織中の菌発育像及び組織反応が証明された時，始めて 本应として診断されるものであると思われる5) 7)-10)。 本邦においても既に多くの真菌症の報告があり, 真菌 
についてる数々の実験がなされているが，剖検例は比較

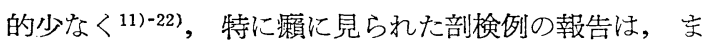
だ見られない。本例は生前並びに剖検時に菌の培養検察 を行つていないのは遺憾であるが，組織的に容易に菌を 証明し，該菌の形態学的所見より，菌種を或程度明かに 乙得たと考えられるので, 妶にその臨状的並びに病理学 的所見の概要を報告する。

\section{臨 牃 的 事 項}

45 于, 男, 職人。

既住歴及び家族歴，特記することは認めない。

昭和 10 年 2 月（24才）, 左前膊部の知覚麻痺を自覚し 左手指の外傷が長期間治瘾しなかつた。濑性班紋は自覚 しなかつた。昭和 11 年 7 月入所。入所時の所見は，顔 面の瀨性浸潤，左側顔面神経麻瘁，嗄声，右側手指の軽 度屈曲, 両側拇指球及び小指球の菱縮, 両側尺骨神経及 び正中神経の肥厚，両側前膊及び手部の著明な 知 覮 麻

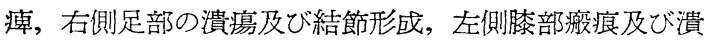
瘍形成，両側腓骨神経及び後脛骨神経の肥厚，両側下腿 部の知覚障碍，同部の軽度の運動障碍及び両側股鼠蹊部 淋巴節の各数個の拇指頭大の腫張等であつた。光田氏反 応除性，顆菌陰性であつた。昭和 26 年以降プロミン 87 本（1本にプロミン $1.5 \mathrm{~g}$ 総計 $130.5 \mathrm{~g}$ ) を注射し，同 31 年 当初には病状以殆んど固定していた。

昭和 31 年 9 月下旬, 全身倦怘, 右側胞部痛 及び 発熱 $\left(37^{\circ} \sim 38^{\circ} \mathrm{C}\right)$ を訴光る。同月 25 日の胞部X線所見に おいて, 右側下肺野に㵢蔓性の雲状陰影, 両側肺門部陰 影及び肺紋理の軽度増強があり, 右湿性肋膜炎之診断し た。特殊の治療をせずに，消炎剤並びに利尿郕等の投与 で軽快した。同年 10 月 20 日，高熱 $\left(39^{\circ} \mathrm{C}\right)$, 著明な咳 嫩及び両側の胞痛等を訴えた。当時の所見。䇔溲し，衰 弱顔貌，皮艮は荅白で乾懆する。咽頭は軽度に発赤す る。両側下肺野の打診音短, 濁, 呼吸音微弱, 声音振璗 滅弱，及び摩擦音聴取等があつた。尿量 1 日 $300 \mathrm{cc} 。 \mathrm{X}$ 線所見では右側湿性肋膜炎の像をみる他著変がなかつ た。胞腔試験穿刺により, 胸水を認め, 該胸水の細胞成 分は主として淋巴球で占められ, リバルタ反応陽性, 蛋 白 $0.5 \%$, 放置すると瀻維索を析出した。喀痰は，漿液 性で，塗抹標本では結核菌及びその他の細菌除性，培湌 で結核菌陰性であつた。血液白血球数 13,400 ，中性好 球の核左方移動があり，淋巴球は軽度に增加していた。 赤沈值 1 時間 $130 \mathrm{~mm}$ ，平均值 $98.75 \mathrm{~mm}$ であつた。利 尿郕，消炎鼡及び I.N.A.H．投与等により，やや小鹿 を保つていた。10月29日よりストマイ $1 \mathrm{~g}(0.5 \mathrm{~g}$ 宛 2
回注射）を 11 月 6 日迄連日使用した。 $37^{\circ} \mathrm{C}$ 台であつた 体温は 10 月 29 日以降 $38^{\circ} \mathrm{C}$ 台に上昇した。11 月 3 日， 食思不振，胆汁様吐物を混ずる嘔吐（1日 4〜 5 回), 及び全身隐㤐を訴えた。咽頭部には著変を認めなかつ た。同 5 日，嘔吐は止まつたが 4 〜 回の下脷があり衰 弱が強くなつた。体温は $37^{\circ} \mathrm{C}$ となり，出液も吸収し 尿量は $650 \mathrm{cc}$ であつた。高度の全身倦怠及び食思不振を 訴之，向 6 日前から咽頭痛，3日前から嗄声及び膿性喀 痰があると訴えた。㸶頭痛のため，開口不能となり，咽 頭所見は不明であつたが，口臭が強く，口腔可視粘膜特

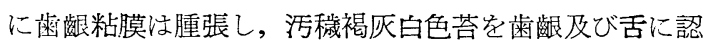
めた。喀痰検査により，結核菌注陰性であつたが，塗抹 標本において真菌の芽胞及び菌系を無数に認的た。真菌 の培養同定は行わなかつた。些頭真菌症の合搠を疑い，

$1 \%$ ゲンチフナヴフイオレット液, 及び $1 \%$ メチレンブ ラウ液の㸶頭塗布を行い，併せてネオシアンコール1日 $2 \mathrm{mg}$ 死亡前日迄 4 日間投与した。脈搏頻数，心音強， 頻, 呼吸音微弱, 左下肺野の小水泡音聴取, 声音掍䔽や や強盛，両下胸部摩擦音聴取，打診音短，腹部の膨隆及 び圧痛等がみられた。右胸腔試験穿刺により滲出液の採 取は不能であつた。6 日体温は $39^{\circ} 6^{\prime} \mathrm{C}$ に達し，全身状 態増悪のため，輸液，強心荗投与等を行つた。11月 7 日，一般状態益々増悪し，胃部及び下腹部痛を訴え，下 脷（1日 2 回）が続いていた。胸部所見には特別な変動 が見られなかつたが，呼吸困難を訴える様になつた。喀 痰検査により，真菌の芽胞及び菌系並びに連鎖状球菌等 を多数認めた。高度の㸶頭痛のため掑食不能となり, 輸 液, 強心凰等の投与を続けた。11月 8 日， $39^{\circ} \mathrm{C}$ 台の発 熱が続き，全身状態は全く不良となり，心音及び脈搏共 に弱く頻となつた。夕方頃より顓固な嘔吐が始まり，11 月 9 日午前 3 時遂に不㴆の客となつた。

\section{病理解剖学的並びに病理組織学的事項}

\section{$\mathrm{A}$ : 病理学的診断 (剖検第 2,804 号)}

1) 真菌症 a) 真菌性肺炎（主と乙て化膿性，一部 乾酪性並びに巨細胞形成性）ｂ）左側線維素性化膿性 胸膜炎並びに左側膿胸 c) 喉頭, 気管, 咽頭及び食道 等の偽膜沈汮性炎。

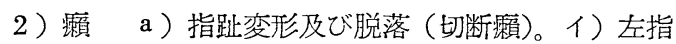
短縮（全指）拇指硬直，小指屈曲位硬直。口）右拇小指 屈曲位硬直，示・中・環指脱落。一）左第一趾脱落，第 二～第五趾短縮。二）右第五趾屈曲位硬直。b）攋性淋 巴腺炎（腹部大動脈周囲，頸部，顎下部，鼠蹊部，腸間

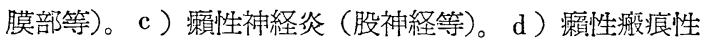


皮度炎。e ) 筋萎縮（両側前膊部笳，両側小指球及び拇 指球，下腿筋等。

3 ）腸狭窄（迴盲部と後腹膜間の線維性索状物の索引 による）及び腸沈瘍。

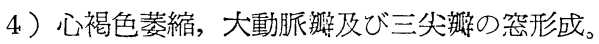

5 ) 両側性線維性肋膜瘾着。

6 ）胃糜爛及び胃カタル。

7 ) 微小出血 (青, 腸, 前立腺等)。

8 ) 諸㶓器の変性 (腎, 肝等) 及び萎縮（脾, 副腎, 睪丸等)。

9 ）軽度大動脈硬变。

10）膀胱カタル。

11）前立腺々性肥大。

12) 褯創。

13）全身咅瘦。

$\mathrm{B}$ ：肉照的所見

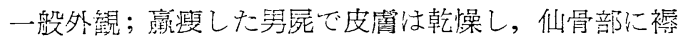
創空認的た。上跂筋法萎縮状で，特に前膊では著明とな

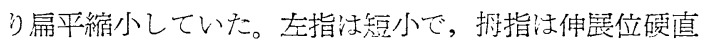
小指冲届曲位硬直䒚呈していた。小・拇指球共に萎縮状 で京つた。右侧注拇指及び小指が屈曲位硬直に抢ちいり 第二〜第四指は欠䁚していた，小・拇指球共に萎縮状で 方つた。下肢筋艺菱縮状で，左第一趾欠損，第二〜第五 趾は短小で山つた。右趾は第五趾分屈曲位硬直を呈して いた。表在性淋巴節注晫度に腫大していた。

胸腔外钼; 左側は上葉に，右側は全般的に体壁肋膜と 肺側肋膜との間に強い婳旧性の癒着があり，両側共に用 手剥離:は团難で亦つた。左側胸腔には膿様の混濁した胸 水省少量容机ていた。

左肺； $755 \mathrm{~g}$ ，部位によつては胼胝性の強い肋膜肥厚を 全般的に認以，表面には線維性物㗨を附着しており，葉 間にも強い别膜瘾着があつた。又下葉の一部には厚い膿

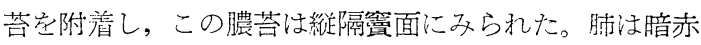
色調がきき強く，埝髪音の聴取は上葉上部においてのみ 良驽で，ての他の部では不良で䒼つた。上葉は全般的に 気腫状を呈し，唯背部及び下葉に接する部においては多 少硬度が増していた。下葉は暗赤色調が強く，硬度も増 していた。肺浮遊試験法上葉湯性, 下葉法泩であつ た。割面に新いて，上葉の上中部では気腫状喿圭るが 上葉の下葉に接方る部及び下葉に沾いては，直径 $2 \sim 4$ $\mathrm{mm}$ の带緑黄色乃至灰白色調の病栄を东，小結節が互に 孤立又は融合し，又一部のもの出以帮面上り污稜な膿

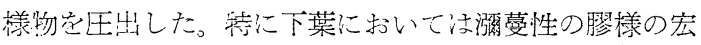
い病采を作り，下葉全体が侵され，こころごころに多少
灭白色調を呈するところがみられた。病巣周囲では，や や硬度を増しており，その他の肺実質は浮腫状で，强く 混濁していた。肺門部淋巴節では軽度に腫大するものを 数個認め，割面は㵦様でやや軟であつた。気管支は膿様 浸出物を容れ，粘膜は混濁充血していた。

右肺； $1,035 \mathrm{~g}$, 全般的に強い肋膜肥厚及び線維性物質 の附着がみられ，特に下葉において著明であつた。各葉 間肋膜は用手剝離不能な程度の強い陳旧性の瘜着を起し ていた。上・中葉では捻曒音の聴取は軽度で気腫状を呈 し，肺浮遊試験は陽性であった。割面では上・中葉共に 気腫状で，限局性病巣等は認的ら机なかつた。下葉及び その気管支では左側と同様の病变をみた。

咽頭，喉頭，気管及び気管支；扁桃には強い血管充盈 の他には著变がなかつた。咽頭部は暗赤色調を呈し，带 緑黄色の偽膜を被る 1 $2 \mathrm{~mm}$ の円形乃至不整形の浅い

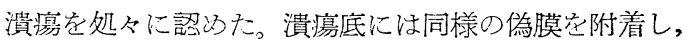
潰湯緑の下掘机はみら机なかつた。硬さは尋常であつ た。偽膜注宏く粘膜面をおおい，剥離は容易であつた。 気管粘膜は湜濁，充血し，分歧部に全るまで带黄灰白色 調をおびていた。気管支には充血及び粘膜の混濁等があ

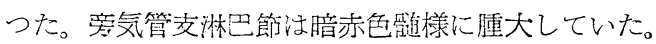

舌及び食道；舌は軽度に浮腫状で腫大しており，暗赤 色調が強く，镈い带黄灰白色調の舌苔を附着していた。 食道治く胿隆し，血管充盈が強く，特に咽頭に近い部

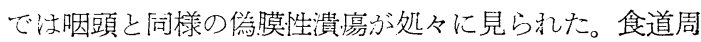
井の淋巴節湆赤色調噵様に腫張していた。

腹腔外観及び他臟器の所見は之を省略する。

$\mathrm{C}:$ 病理組織学的所見

肺；肋膜は高度に増殖肥厚し，血管腫状に増殖してい る血管の新生が一部にみら机る。增殖結合織中には淋巴 球，小円形細胞，多核球及び大単核球等の炎症性細胞の 浸潤がみられる。体壁肋膜と癒着しない部では表面に線 維素を附着し，同時に多核球を主とする細胞浸潤がみら れる。肺組織は一部気隀状を呈するが，全般的に炎症性 反応が強く，血管充盈が顕著で水腫及び炎症性細胞浸潤 が高度にみられる。部位によつては大小の膿瘍を形成 し，炎症性細胞の浔潤及び線維素の析出等がある。膿瘍 壁淌形成されないものが多い。やや旧いものでは多核 球沙く, 主として大単核細胞芯混光ている。部位によ つては主として多核巨細胞及び組織球の集簇栄を形成 し, 又弱芽な肉芽の形成意伴う部もある。膿瘍周囲の肺 胞は圧平され，肺胞壁及び肺胞内にも渗出物，とくに線 維素及び獎液の滲出がつよい。又他の一部には乾酪化单 の形成を認め, 組織の面影を止的ているところが見られ 
る。気管枝腔注剝離した上皮及び炎症性細胞等で 充さ れ, 壁にも炎症性反応が見られる。部位によつては間質 結合織の軽度の増殖が認められる。

Goodpasture Mac Callum 染色, Mc Manus 染色及び その他等により Gram 陽性の (偽) 菌糸及び胞子を多数 認的る。これらは肺胞内, 肺胞壁病单中に不定散在的に 認わられる。膿瘍部に浽顕著に見出され，特にての辺渌 部附近に著明でする。文乾酪单にもかなり多数発見され る。（偽）菌系体は分節並びに分芽状で, 各 (偽) 菌系 の接合部が狭小となつているものが多い。胞子は遊㒕 状，分節状又㤋芽状又（偽）菌系に連接与るもの等

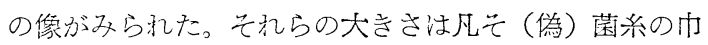
$0.5 \sim 1 \mu$, 非さ $5 \sim 10 \mu$, 胞子は直経 $0.5 \sim 3 \mu$, 巨 大胞子汶 $7 \sim 10 \mu$ であた。

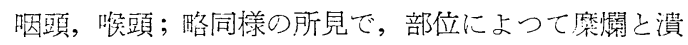
㾤が劣り，漬癔縁は壞死状で，多核球，大学核細胞及び 小円形沺胞等の浸潤定伴う。その他に癩性の旧い变化と

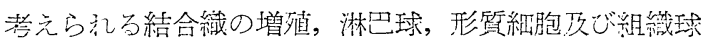

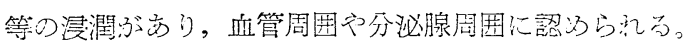
又腺組織の間啠の堌殖它認的るところが㐫る。

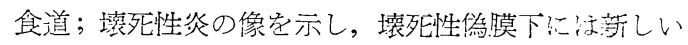
炎店性反応が強い。

咽頭，喉頭，食道等の琵死部及び鸴嗼等には Gram 湯 性で，P．A．S.染色で据染子る肺之京様の真菌々系，

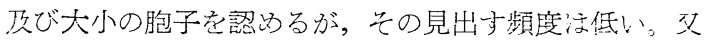
こ机らは潰演底及び粘膜固有層等にも見られる。

皮膚; 上肢，下肢及び腹壁等のものについて観祭した が，何れにおいても萎縮状で，上皮注菲薄となり，乳頭

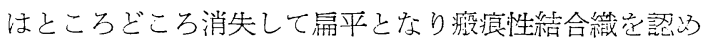
る。汗腺法著るしく萎縮状で腺細胞に奕性变化壳認的, 周囲に小円形細胞の浸潤が㐫る，又业管周囲等にも小円

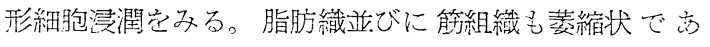
\%。

淋節; 腹部大動脈周团, 頸部, 顎下部, 鼠䟡部反び

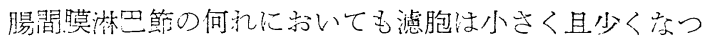

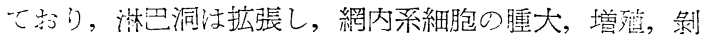
離があり，多数の泡泝状細胞をみる。頸部のものには，

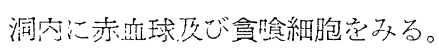

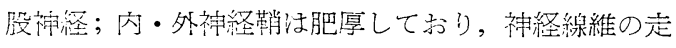

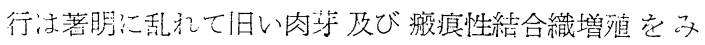
る。

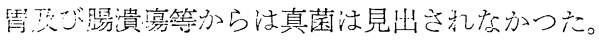

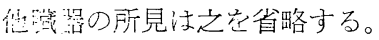

\section{総括並びに考按}

本例は以上の如く，その臨床的事項と病理学的所見加 ら主として真菌症性変化と癩性病変との二病变からなつ ていること范知つた。この内特て興味あるものはその真 菌症に就てである。

人体にみら秃るモニリア症を大森2゙は１）皮膚を主 に侵与型 2）口挖, 咽頭, 舌を主に侵寸型 3) 腸管 を主に侵す型 4) 呼吸器を主に侵す型 5) 敗血症感 染艺起声型等に区別し，前三者の矛後は良好，4）はや や不良５）は不良としている。この分類汃らみるな 壮本例湔述の所見よりして4）に相当与るものである と考えられる。

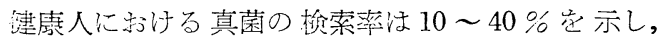
5).23)-25) 肺症状のあるものは，上引高率に発見さ光，中 でも抗生物質意大量に渎用したものには，夏に高い頻度 を示している。特に結核に続発したものでは結核と類似

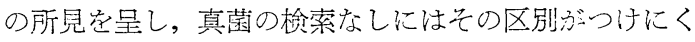
い場合があるとされている34。本例においては，肺は肉 跟的に灰白色結節状の凝固壊死栄が孤立又注互に融合し て尔り，結核の乾酪化に類似の病巣荌呈していたが，組 織的には小膿湯の形成があり, 線維素の強い析出, 浮腫 欠び腫瘍周囲の高度の滲出性乃至線維索性滲出性炎を

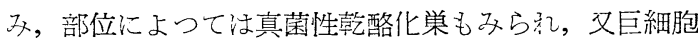
を伴う弱若肉芽を認的たが，結核結節とは明らかに異る

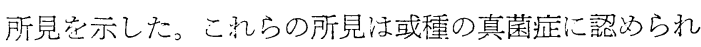
る特異の炎症性资化で市ると言える。

沖中 ${ }^{26)}$ 等によると人体にみら扎る病原性真菌症学内团 性及び外因性に分けているが，言葉の上から内在性及び 外来性とした方がよいと思わ机る。この内在性のものに Candidiasis, Geotrichosis, Actinomycosis, 攻び Crytrococcosis 等があり，外来性の导のに Aspergillosis, Penicillosis, Blastomycosis, Coccibiomycosis, Histoplasmosis 及 び Nocardiosis 等が挙げられている。Candida 属は25種 と 8 变種と言われ，特に Candida albicans は人体にの み発見されるとしている。中沢 ${ }^{27}$ は は Candida 属に 30 種 と6変種を区別している。組織内に（偽）菌糸及び円型 体の見られるものとしては Candida 属, Aspergillus 属, Mucor, Madurella 属, Monospirium apiospernum, Trichophyten, Monosporum, Epidermophyten アび Malasseziafurfur 等があり28), 又高橋29), 堂野前30) 攻び高憍

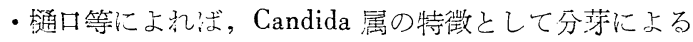
醉母細胞を主として之に偽菌系究生じ，分芽細胞を撯生 するとしている。他檑との相違点として巨大な厚膜胞子 
を生ずることであるとしている。同様の厚膜胞子は Aspergillus 属にも見られるものである。本例において は（偽）菌系，胞子並びに特有の巨大胞子を認め，該 巨大胞子は厚膜胞子と考えられ，このことふら本例 は Candida 属が最も疑われ，次に Aspergillus 属が考えら れるが，この両者以外のものは形態的観点よりして除外 出来ると思わ机る。

本症に見られた様な (偽) 菌系の所見について，小林 等 ${ }^{22}$ は炎症に伴つて出現した線維素が乾酪化の波及を免 れて，まだ破壊されずに残存する線維素が染出されたも のであろうとしており，組織内真菌々糸の検出に当つて は，あくまでもその形態像を第一義的とすべきであると している。奥平 ${ }^{33)}$ は Canda albicans と Aspergrllusfumigatus との相違点をその染色性並びに形態的観点から 報告している。染色性は Hematoxylin Eosin 染色では Candida は一般に不染性であり，東結切片ではわずふに Hematoxylin に染まるが, Aspetgillus では Hematoxylin に弱くもしくは強く染まり，菌系の横断面では Eosin に 染まる不定形の物質を持つ輪状物として見えるとしてい る。又 Mc Manus 染色では Candida は Schiff の液に 均質性に強く染まるが，Aspergillus では中等度陽性で あり，大部分の菌杀においては，その内部構造が観察さ れるとしている。文 Gram 染色では Candida は強染性 で一般に均質性であるが, Aspergillus では中等度陽性で その内部構造が強陽性であるとしている。本例において は, Hematoxylin Eosin 染色, Mac Manus 染色及び Gram 染色及び染色等を行つて観察したが，その染色性 は奥平の報告の様に Hematoxylin Eosin に不染性, Mc Muunus 染色及び Gram 染色により，いゔれも強陽性， 均質性であつた。この染色性並びに形態的な所見からも Candida 属であると考光るのが最も妥当であると思われ る。

Louis ${ }^{35)}$ によると 250 例の Candida の 中，原発は 4 例のみに見られたとし，堂野前は自験例 ${ }^{8)}$ を含的て日本 におけるモニリア症を次の如〈啹告している30)。沉発性 で原発性のもの 6 例, 続発性 5 例, 呼吸器禾で原発性 7 例, 続発性 24 例, 消化器系で続発性 5 例計 47 例であり 続発性法 34 例である。この呼吸器系続発性 24 例の中, 6 例は腸結核に，11 例は肺膿瘍又は肺壊疽に続発して おり, 病理組織像として, 膿瘍形成は一次感染で法第 3 週に, 又再感染では第 1 週に見られるとしている。しか 乙武内等 ${ }^{36}$ 注実験的醉母菌症では, 菌注射後 $2 \sim 3$ 日で 既に臟器内に膿瘍の形成を証明している。勿論それは真 菌の毒力にも関係がある。いずれにしても真菌症は臨床
的に何らかの原疾患に続発するものが多い。殊に呼吸器 系のそれは結核症において登病率が高い。本例は長期間 にわたる蟦療養生活を送つており，真菌症が瀨に続発し たものであるか否かは䏌充分明らかでないが，本真菌症 が呼吸器系殊に気道及び肺に主要病変を作つているとこ ろを見ると，それが原発性でないとするならば，この部 の病変に誘因を認めなければならない。それにも関らず 陳旧性肍膜瘢痕以外には，該部には結核性病变を全く認 わず，寧万気道には陳旧性癩性浸潤万至瘢痕性病巣を認 めるのみであるので, 或はこれらの原発性病変の基磐の 上に真菌の発育炎招来し, それの毒力が強化され, 或は 癩患者の体力の低下と相俟つて本症の発症を促したもの ではないかとみられる。臨床的湿性肋膜炎はこれら病変 の進行の一過程であつて, 結核とは無関係であることが 明らかにされ，更に後述する様に抗生物質の使用が本应 を更に増悪せしめたものとみられるのである。しかも瀬 菌は結核菌と同様に抗酸性菌であると言う共通点におい て，本症の発症は興味あるものと考学られる。

真菌症は 40 才以上の成人に多く見られ行年.30), その発 病機転について堂野前30) 弱 2）抗生物質投与の影響 3 ）混合感染等としてお り，本邦の真菌症 47 例の全例が 1 種若しくは数種の抗 生物質を使用し，こ机によつて真菌症を誘発したような もの 19 例，覀化を見たもの 14 例，病状一時改善後，再 び悪化したもの 8 例と，殆んど全例が何らかの悪影響を 受けているようであるとしている。本例においては本症 発症前にはプロミン以外には特別な薬品を使用していな いし，又プロミンはかなり以前より使用しているので， それが本症の発病の誘因となつたという様なことは推察 しにくい。しかしストレプトマイシン使用当日より急激 に $38^{\circ} \mathrm{C}$ 台の発熱炎み，且咽頭痛の招来されたこと等よ りしてストレプトマイシンが本真菌症を急激に悪化させ たものではないかと考えられる。

先述の如く䍜に合併した気道ないし肺真菌症の報告は まだ見られないが漂発症及びその他により個体の抵抗力 の減弱を来して, 真菌店の発生を招来し, 抗生物質の使 用等が更にその増瑟を助長して, 本例の如くなる場合が 考えられ, 瀨そのものと真菌症との因果関係は直接的な ものは恐らく無いと考えられるが, 本例の様な発症様式 もあることは今後考慮されなければならないであろう。

\section{結語}

1）瀨にみられた肺真菌症の一剖検例を報告した。

2) 本真菌は生前並びに剖検時にその同定を行わなか 
つたことは遺憾であるが，その形態的並びに染色性等の 所見よりして Candida が強く考えられるが，Aspergillus も完全には除外し得ない。

3) 本真菌症は気道の癩性病変に続発したものと考え られ，特にストレプトマイシンを使用することによつて それを増悪せしめ，死の転㷌をとらせたものと考えられ る。

（稿を終るに当り終始懇切な御指導を戴き，又御校閲 を賜わりました恩師久保久雄教授, 武内忠男教授並びに 国立療養所菊池惠楓園々長宫崎松記博士に樑甚の謝意を 捧げます。)

\section{参 考 文 献}

1 ）美甘；抗生物質とモニリア：日本臨床，10，2， $105 \sim 116$, （昭 27）

2）大森；モニリア症について：新舄医会誌，66,11, 786,（昭 27）

3 ）東郷；抗生物質療法に見られるいわゆる菌交代現 象と粘膜皮膚の变化並びに真菌類の出現: 医学のあゆ 夕，14. 2，76〜82，（昭 27）

4）樋口，岩崎；抗生物質によるモニリア症の発生に ついて：福岡医誌，44，8，629～640，（昭 28）

5 ）樋口，岩崎；モニリア症，とくに本症と抗生物質 との関係: 日内会誌，42，11，852 854, (昭 28）

6 ）美甘他；抗生物質之真菌症：治療，36，2，148～ 154, （昭 29）

7) 林, 清水; 気管枝モニリア症：医内小，6，556～ 558 , （昭 26）

8 ）堂野前他；肺モニリア症自験二例について：日本 臨床，11，1，29４1，（昭 28）

9) 大久保; 内科的 Candida 症の臨状的診断法につ いて: 臨床病理，2，3，223～226，（1954）

10）岩田；モニリア症の診断について：モダンテラピ 一，7，9，6〜11，（昭 29）

11）土本; Moniliasis of Lung. : 東京医新， 99，9, 514 516，（昭 27）

12）堂野前, 松本; 沉発性乇ニリア症：日本臨床, 10, $3 ， 201 \sim 206$, （昭 27）

13）久米他; 結核性脳膜炎に併発せる沉モニリア症

（会）；名医学，67，308～309，（昭 28）

14）国枝他；汎モニリア症について（会）：名医学, 67，391，（昭 28）

15) Z. Ishii and Y. Maruyama ; Cervical Granulomatous Nocardiosis an Autopsy Case of Cervical Lym- phnode Swelling Simulating Hodgkins Disease. : Acta Path. Japonica, 5, supple., 577 581, (1955)

16) Y. Yamamoto ; An Autopsy Case of Disseminated Mycotic Disease. : Acta Path. Japonica, 5, supple. 583 591. (1955)

17) I. Nishimori ; A Case of Mycotic Infection of the Stomach and Liver Found in a Panmyelophthisis Patient who was Exposed to the Atomic Bomb Rediation in Nagasaki : Acta Path. Japonica, 5, supple. 593 〜598. (1955)

18）螺良; 沉発性モニリア症, 肺モニリア症及びその 治療の問題: 臨床病理, 2, 3, 211 218, (1954)

19）小野；モニリア症の三剖検例（会）：日病会誌, 43, 総会号, 504 505, （昭 29）

20）後藤他；沉発性モニリア痁の一例（会）：日内会 誌, 44, 4, 317, （昭 30）

21）那須, 塩沢; 汎発性真菌症の剖検例：綜合臨状, 4，137〜147，（昭 30）

22）安田；最近における当教室の剖検例にみられた真 菌症について (会): 東京慈大誌, $70,11,1317 \sim 1318$, (昭 30 )

23）岡島; Candida 属に関寸る研究（1）（会）: 名医 学, 67, 309, （昭 28）

24）尾関他; Candida 属における臨床的研究第 3 報 （会）：名医学，67，309，（昭 28）

25）吾孫子; 内科領域における Candida の研究：南 大阪病院医誌，1，1，8～12，（昭 28）

26）沖中他；抗生物質と真菌症：臨床病理， $2,3,196$ 〜203, (1954)

27）中沢；乇ニリア症の病原菌，Candida 属について ：日本臨㕅，12，6，556～559，（昭 29）

28) Canant, Smith, Baker, Callaway, Martin ; Manual of clinical Mycology, II nd Edition. (1954)

29）高橋；病原性真菌の分類：臨床病理， 2，3，173 〜180, (1954)

30）堂野前；モニリア痁：日内会誌，44，6，477～ 519 (昭 30)

31）高橋，跲口；日本皮膚科全書，X，2，（昭 31）

32) 小林他; 組織乇ニリ丁様像の検討（会）：名医学 $67 ， 391$ ，（昭 28）

33) M. Okudaira ; Histopathological Differentiation Between Candidaalbicans and Aspergillus Fumigatus in Tissue Sections : Acta Path. Japonica, 5, 2, 117 124, (1955) 
34）甘美，上蒙；結核とモニリア症（会）：結核，26, 9〜11，521～522，（昭 26）

35）Louis；34）より引用

36）武内，巟玉，小島；実験的醸母菌症とフオスファ ターゼ反応；淽州医誌，39，3，461～468，（昭 18）

\section{附 図説 明}

1 ) 肺, $\mathrm{H} \cdot \mathrm{E}$ 染色 $100 \mathrm{X}$ ：膿瘍の部

2 ）同上 $100 \mathrm{X}$ : 膿瘍周囲の部, 強い線維素 の析出，大単核細胞及びその他の炎症性細胞の滲潤等。

3）同上 $800 \mathrm{X}$ ：巨細胞が集つて幼弱な肉 芽を形成しようとする傾向を示す。

4）肺 Gram 染色 800X：Gram 陽性の孤在した又泣 分芽状，及び分節状の胞子，（偽）菌䒺。

5 ）同上 $800 \mathrm{X}$ : 同上。

6）同上 $1000 \mathrm{X}$ : 同上。分節細胞が著明。

7 ）同上 $1000 \mathrm{X}$ ：Gram 陽性の厚膜胞子及び その分芽及び孤在する胞子。
8 ）胭頭部粘膜 Mc Manus 染色 $800 X$ ：厚膜胞子及び その分芽と（偽）菌系。

1. Lung (H. E Stain): Typical abscess is shown.

2. Lung (H. E Stain): Marked exudation of fibrin, infiltration of large nucleates and othex inflammatory cells were seen around the abscess.

3. Lung (H. E Stain): Many giant cells are found in the young granulation tissue.

4-6. Lung (Gram's Stain): Blastospores, arthrospores and (pseudo-) hyphae in the lesions are positivery stained.

7. Lung (Gram's Stain): Chlamydospores and its budding cells stained positively were seen in the abscess.

8. Pharyngeal mucous membrane (Mc Manus Stain): Chlamydospores, budding cells and (pseudo-) hypha are stained in the dseudomembrane. 

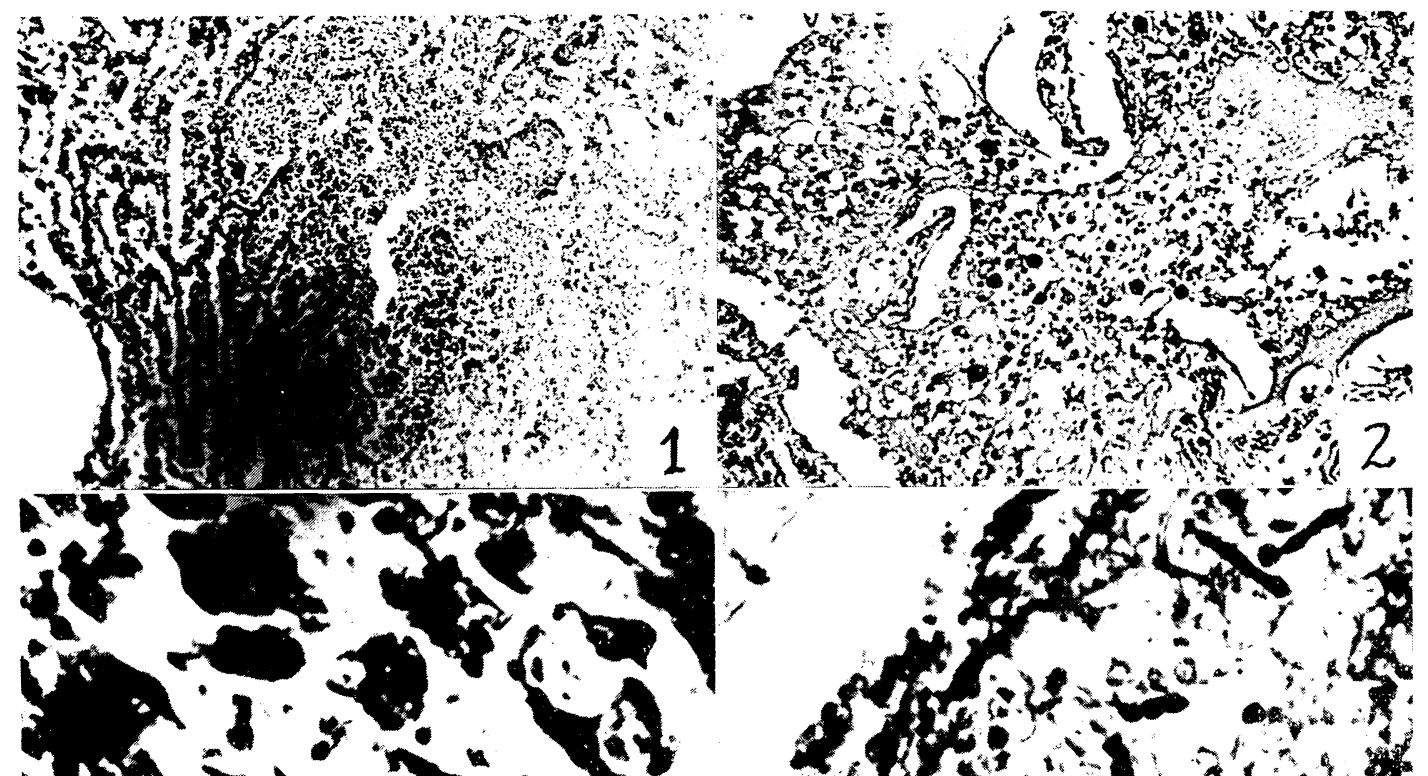

2.

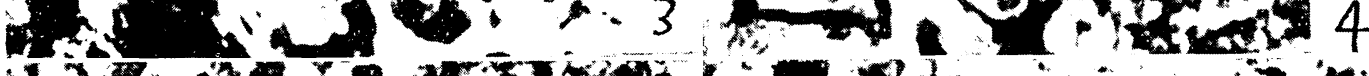

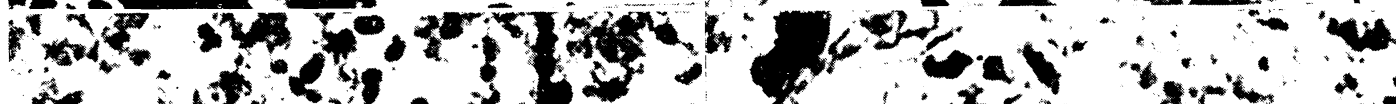

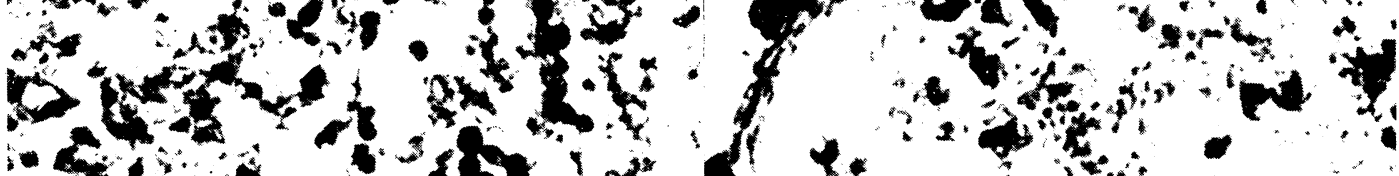

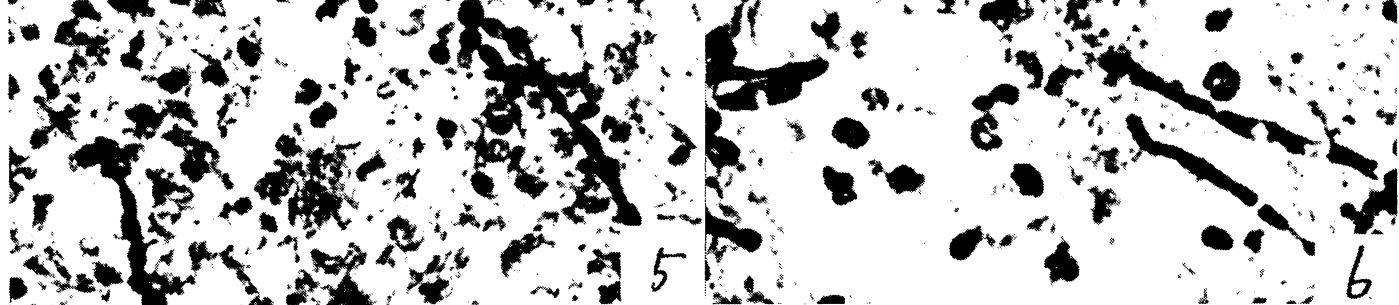

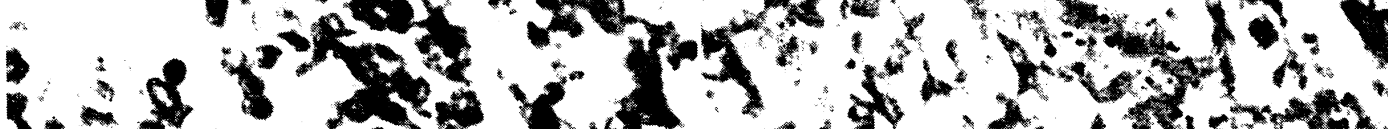

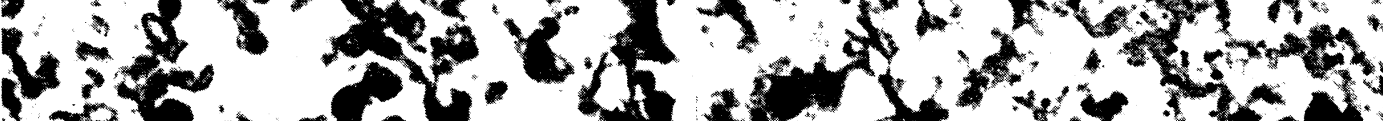

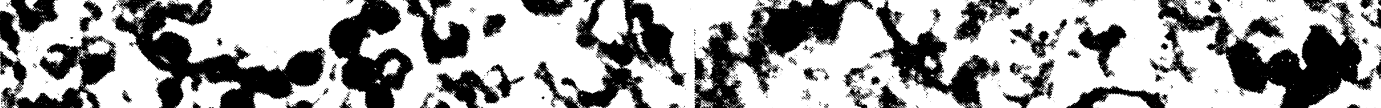

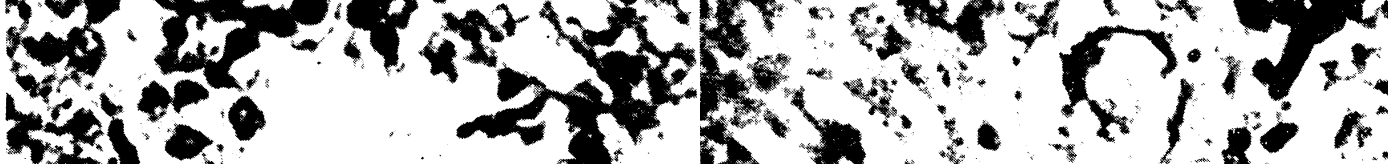

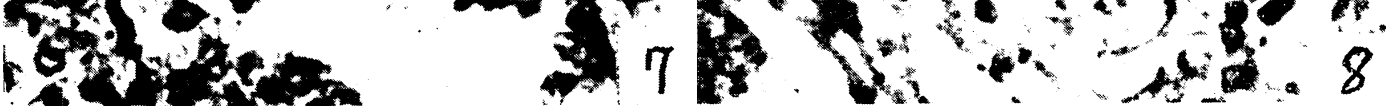

